\title{
Risk assessment for large African hive beetles (Oplostomus spp.)-a review
}

\author{
Benjamin P. OldROYD ${ }^{1}$, Michael H. AllsopP ${ }^{2}$ \\ ${ }^{1}$ Behaviour and Genetics of Social Insects Laboratory, Macleay Building A12, University of Sydney, Sydney, NSW \\ 2006, Australia \\ ${ }^{2}$ Honeybee Research Section, ARC Plant Protection Research Institute, Private Bag X5017, Stellenbosch 7599, South \\ Africa
}

Received 30 October 2016 - Revised 1 January 2017 - Accepted 13 January 2017

\begin{abstract}
We review the biology of two species of large African hive beetle Oplostomus haroldi and Oplostomus fuligineus (Coleoptera, Scarabideae, Cetoniinae). We argue that they have the potential to become invasive and highly damaging to beekeeping worldwide. We provide descriptions of all life stages that should aid in the identification of the beetles. Adult beetles prey on bee brood, whereas larvae and pupae live in dung. Up to 700 beetles have been reported in individual colonies in Kenya.
\end{abstract}

honey bees / large African hive beetle / invasive species / pest species

\section{INTRODUCTION}

Honey bees (genus Apis) underpin the honey industry worldwide (Crane 1990; Oldroyd and Wongsiri 2006). Furthermore, they are critical pollinators. About one third of crop production is animal pollinator dependent, and the majority of pollinators are honey bees (Klein et al. 2007; Aizen et al. 2008). The overall health of honey bee populations is therefore of global economic significance, and central plank of global food security (Klein et al. 2007; Garibaldi et al. 2011). Honey bees are also keystone pollinators in many natural environments (e.g., Roubik 1989; Roubik 1993; Aebi et al. 2012), and in some regions can enhance or replace the role of native pollinators that have been lost due to

Electronic supplementary material The online version of this article (doi:10.1007/s13592-017-0493-7) contains supplementary material, which is available to authorized users.

Corresponding author: B. Oldroyd,

Benjamin.Oldroyd@sydney.edu.au

Handling editor: Peter Rosenkranz anthropogenic changes (Corlett 2001; Rader et al. 2009; Brittain et al. 2013).

Alarmingly, despite the dependence of modern agriculture on managed bees for pollination (Aizen et al. 2008), there are increasing threats to honey bee populations (Potts et al. 2010) arising from the anthropogenic spread of honey bee pests and diseases (e.g., Oldroyd and Wongsiri 2006; Mutinelli 2011). Less than 35 years ago, the majority of commercial honey bee populations worldwide were free of some or most of the pests and diseases that are now of major economic importance, including Varroa mites (Varroa destructor), European foul brood (Mellisococcus pluton), chalk brood (Ascosphaera apis), tracheal mites (Acarapis woodi), and small hive beetles (Aethina tumida) (Bradbear 1988). An optimist might take comfort in the notion that the worst is now over, but even a casual acquaintance with native honey bee populations in Asia (Chantawannakul et al. 2016) and Africa (Pirk et al. 2016) reveal that there are numerous parasites and pathogens that could potentially move from their native range and host species to parasitize Apis 
populations internationally or shift hosts to honey bees (e.g., Ellis et al. 2008; Audisio et al. 2014). Similarly, there is a potential for viral, fungal, and bacterial diseases from commercial A. mellifera populations of Europe, the Americas, and Australasia to spread to the Asian honey bee populations (Chantawannakul et al. 2016). Global trade in beekeeping equipment, raw beeswax, package bees, and queen bees provides enhanced opportunities for spread of pests and diseases (Mutinelli 2011). Additionally, some insect pests can be transferred via agricultural products, machinery, and soil.

Small hive beetle Aethina tumida (hereafter $\mathrm{SHB}$ ) is a contemporary example of an African pest species that has recently spread to A. mellifera populations outside of Africa, causing widespread havoc. SHB is endemic to sub-Saharan Africa including Madagascar (Swart et al. 2001; Neumann et al. 2016). In Africa, it is but a minor pest of beekeeping, only affecting weakened colonies and stored honey combs (Hepburn and Radloff 1998; Pirk et al. 2016). However, SHB typically assumes major pest status outside its native range (e.g., Elzen et al. 1999; Hood 2004; Neumann et al. 2016), especially where the honey bees are of European descent, and the climate is warm and humid (Neumann and Elzen 2004). Since it was first detected outside its native range, in North America in 1996 (Hood 2000), SHB has spread to North Africa in 2000, Australia in 2002, Europe in 2004, the Caribbean in 2005, Central America in 2007, South America in 2013, and Asia in 2014 (Neumann et al. 2016). Interestingly, the Australian genotype appears to be genetically distinct from the North American population, suggesting that it was an independent introduction from Africa (Evans et al. 2000).

The threat posed by SHB to beekeepers outside of Africa was not recognized until after it became established in the USA. It is therefore important that we evaluate the risks associated with even minor pest species of honey bees within their native ranges in Africa and Asia. As the SHB (and indeed the Varroa) experience shows, a species that is of minor pest status within its native range can be disastrous when introduced elsewhere. The change in pest's status can arise from the absence of parasites and pathogens that keep a pest species at low population levels in its native range, a lack of resistance in the newly exposed hosts, or simply a set of environmental conditions that favor the fecundity of the pest species (Colautti et al. 2004).

In this review, we highlight the threat of large African hive beetles (hereafter LAHB) of the genus Oplostomus to world apiculture. Unlike SHB, which causes minimal damage in its native range, LAHB can cause a significant damage to honey bee colonies within its native range in southern Africa (Swart et al. 2001; Fombong et al. 2013). We provide descriptions of its biology and life cycle and assess potential routes of entry into countries outside of Africa.

\section{TAXONOMY AND IDENTIFICATION}

LAHB are in the family Scarabaeidae, subfamily Cetoniinae (flower chafers). There is a minor confusion in the literature about the taxonomy of LAHB, at genus level. Johannsmeier (1980) refers to the major pest species as Hoplostoma fuligineus. However, the synonym Oplostomus fuligineus Oliv is preferred (Donaldson 1989). A related species, $O$. haroldi Witt also enters bee colonies and feeds on brood.

$O$. haroldi is distinguished from $O$. fuligineus by the shape of the clypeus (upper lip of the mouth). The clypeus has rounded edges in $O$. fuligineus while the clypeus of $O$. harold $i$ has sharp edges, which make it appear rectangular. $O$. fuligineus is black throughout the dorsal surface, whereas $O$. haroldi has a variety of body colors that include all black body, black with reddish brown stripes, and black with orange stripes (Figure 1; Fombong et al. 2013).

A 680-bp region of the mtCOI gene can be amplified by PCR using the "bar-coding" primers LCO-1490 (5' GGTCAA CAAATCATAAAGAT ATTGG 3') forward and HCO-2198 (5' TAAACTTCAGGGTGACCAAAAAATCA 3') reverse (Folmer et al. 1994). When sequences so obtained are queried against Genebank using Blast, the best match is to the appropriate sequences (O. haroldi or O. fuligineus) lodged by Fombong et al. (2013) (Genbank accession numbers JQ658361-JQ658374) (Oldroyd and Allsopp 2016). 

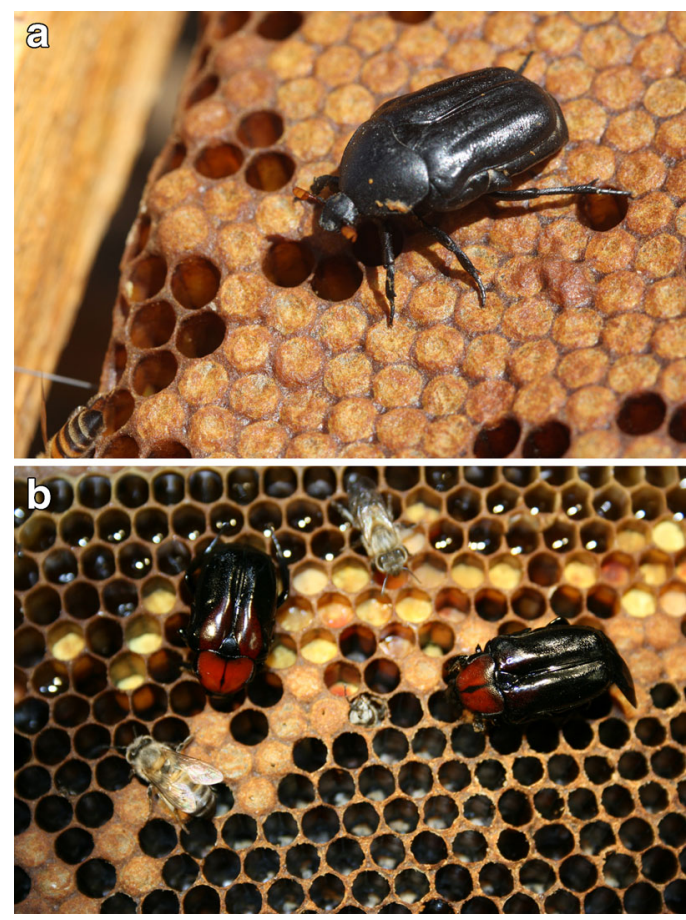

Figure 1. Adult large African hive beetles. a Oplostomus fuligineus (Photo B. Oldroyd). b O. haroldi (Photo M. Allsopp).

\section{DISTRIBUTION}

O. fuligineus has been reported from Botswana (Clauss 1983), Zambia (Silberrad 1976), Namibia (Eggers and Wurst-Henning 1944), Kenya (Fombong et al. 2013), Zimbabwe (personal observations of MHA and Papadopoulo 1964), Senegal (Ruter 1975), Nigeria (Oyerinde and Ande 2009), and South Africa (e.g., Johannsmeier 1980; Donaldson 1989; Swart et al. 2001). O. haroldi has been reported from Kenya (Torto et al. 2010; Fombong et al. 2012a, b; Fombong et al. 2013), Botswana (personal observations of MHA), Zimbabwe (personal observations of MHA), and South Africa (Johannsmeier 1980; Oldroyd and Allsopp 2016). Some of these reports are provisional, because in some cases, the species may have been confused. However, based on this limited information, we believe that both $O$. haroldi and $O$. fuligineus are found throughout sub-Saharan Africa. Based on the study of Fombong et al. (2013) in Kenya and our own observations in South Africa, it seems likely that $O$. haroldi prefers wetter (often coastal) areas, and $O$. fuligineus prefers dryer grazing land where dung is abundant. Clauss (1983) states that $O$. fuligineus is absent in very dry areas like the Kalahari Desert in Botswana.

\section{DESCRIPTION OF THE ADULT}

O. fuligineus beetles are heavily armored (Figure 1). The average length is $2.1 \mathrm{~cm}$ and head width $3.3 \mathrm{~mm}$ measured between the eyes (Oldroyd and Allsopp 2016). Adults are uniformly black except for the terminal segment of the antennae, which is orange (Figure 1). Antennae are shielded and are usually tucked under the head, which prevents biting attacks by bees (Fombong et al. 2013). The terminal segment of the antenna is lamellate, elongated, and flattened. There are six segments on the flagellum. There is a very little sexual dimorphism. The sternites of the female are more rounded than in the male, and males feature a groove on abdominal sternites 2 and 3 that sometimes extends sometimes to the 5th sternite (Donaldson 1989).

Oplostomus haroldi are similar to O. fuligineus but often have prominent stripes on the elytra (Figure 1).

Excellent images of $O$. fuligineus are available at http://www.forestryimages.org/browse/ subinfo.cfm?sub=60497

\section{IMMATURE STAGES}

Descriptions of the pre-adult stages are summarized in Table I. Eggs are small and white, increase in size as the embryo develops, and absorb moisture (Donaldson 1989). The larvae are of typical scarab beetle larval appearance (Figure 2). There are three instars.

Pupae develop in a chamber within the dung eaten during the larval phase (Figure 3). Early pupae are white but darken to reddish brown before eclosion. The developing elytra are folded forward (Donaldson 1989).

\section{LIFE CYCLE}

Development times under laboratory conditions are given in Table II. Eggs are laid in cattle 
Table I. Summary descriptions of the pre-adult stages of the large African hive beetles

\begin{tabular}{|c|c|c|}
\hline Stage & Oplostomus fuligineus & Oplostomus haroldi \\
\hline Eggs: white, oval & $2-3 \mathrm{~mm}$ long & $2-2.5 \mathrm{~mm}$ long \\
\hline $\begin{array}{l}\text { Larvae: typical appearance of } \\
\text { a Scaribadeae larva }\end{array}$ & $\begin{array}{l}\text { Head orange with dark eyes, head width } \\
5 \mathrm{~mm} \text { in mature larva, eight prominent } \\
\text { spiracles on abdomen }\end{array}$ & $\begin{array}{l}\text { Head brown, } 3-6 \mathrm{~mm} \text { wide in } \\
\text { mature larvae }\end{array}$ \\
\hline $\begin{array}{l}\text { Pupae: develop in a small chamber } \\
\text { dug into dung }\end{array}$ & $\begin{array}{l}\text { Start creamy, darken with age to reddish } \\
\text { brown }\end{array}$ & Start creamy, darken with age \\
\hline Reference & Donaldson (1989) & Fombong et al. (2012a, b) \\
\hline
\end{tabular}

or horse dung where they hatch after 6-9 days (Donaldson 1989).

When offered a choice of cow dung, horse dung, straw, or sand under semi-natural conditions, Oplostomus fuliginius preferentially oviposited in horse dung with limited reproduction in cow dung (Oldroyd and Allsopp 2016). Nonetheless, adults will lay in cow dung, and larvae will grow to pupation in cow dung (Donaldson 1989).

Larvae (Figure 2) feed on the dung and pupate after 30-38 days within the dung (Figure 3). Adult beetles are strong flyers and enter honey bee colonies where they feed on brood and pollen. Adult beetles are attracted to volatiles emitted by honey bee colonies (Fombong et al. 2016). The typical period of residence is unknown, but in our trials, beetles remained alive in colonies for more than 30 days (Oldroyd and Allsopp 2016). Males probably remain in colonies awaiting further mating opportunities whereas females leave colonies after mating (Fombong et al. 2016). Adult beetles caged in wooden boxes at a room temperature survived for at least

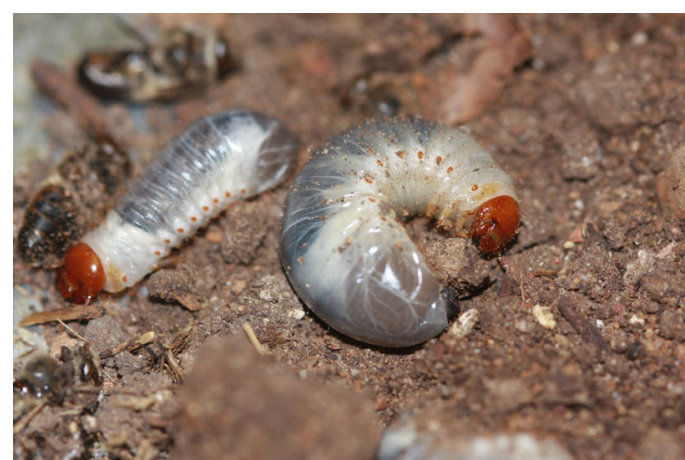

Figure 2. Second and third instar larva of Oplostomus fuligineus (Photo B. Oldroyd).
1 month without food or water (Oldroyd and Allsopp 2016).

\section{DIET}

Adult $O$. haroldi are attracted to volatiles from worker honey bees and pollen (Torto et al. 2010). When offered a choice of fruit, honey, pollen, or honey bee brood adult, $O$. fuligineus preferentially feeds on brood (Oldroyd and Allsopp 2016). There is a strong preference for larvae over pupae, but when there is no choice available, beetles will feed on sealed brood, stored pollen, honey comb, and even fruit (Donaldson 1989; Fombong et al. 2013; Oldroyd and Allsopp 2016). O. haroldi also preferentially feeds on brood, but the preference is stronger in females than in males (Fombong et al. 2013). It is apparently necessary for $O$. fuligineus females to feed on bee brood in order to lay eggs; honey and pollen are not sufficient (Donaldson 1989).

In addition to the brood of honey bees, O. fuligineus can prey on the brood of paper

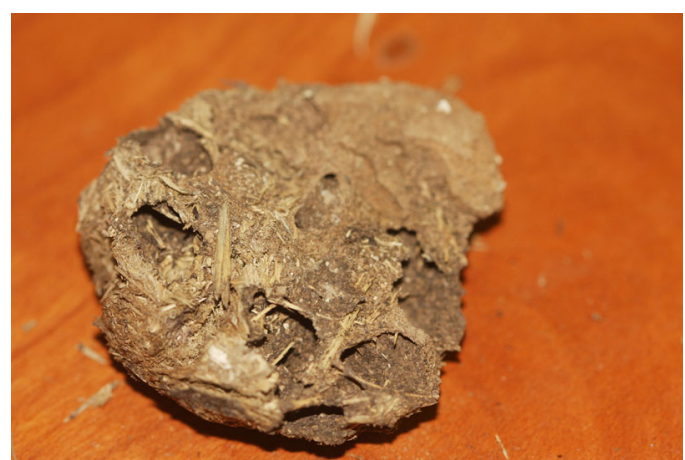

Figure 3. Emerged pupal cocoons in cow dung (Photo B. Oldroyd). 
Table II. Development times of immature stages of large African hive beetles

\begin{tabular}{lll}
\hline Stage & \multicolumn{2}{l}{ Development time (days) } \\
\cline { 2 - 3 } & Oplostomus fuligineus & Oplostomus haroldi \\
\hline Egg & $6-10$ & $7-13$ \\
Larvae & $30-38$ & $29-40$ \\
Pupae & $21-29$ & $26-49$ \\
Adult: emergence to egg laying & Unknown & $60-70$ \\
References & Donaldson (1989) & Fombong et al. (2012a, b)
\end{tabular}

wasps (Clauss 1983; Keeping 1984; Donaldson 1989). This provides an alternative host to honey bees, which could potentially enhance population size should the beetle become established as an invasive population in an area where paper wasps are abundant. Therefore, in addition to its affects on beekeeping, there is a potential for adverse environmental effects.

The life cycle of $O$. fuligineus is summarized in Figure 4. Beetles overwinter in the pupal stage in dung and emerge as adults in late spring following rain (Johannsmeier 1980; Swart et al. 2001). Adults enter bee nests and feed for $30+$ days. Females exit the colony, find appropriate dung, burrow into it, and lay $30+$ eggs. It seems likely that under favorable conditions, the beetles could complete 3-4 life cycles per year. Both males and females are found in hives (Fombong et al. 2013), and both males and females will burrow in dung. Mating has been observed inside beehives, but it is not known if mating also occurs outside bee nests (Fombong et al. 2012a, b). A movie showing adult beetles burying into dung is provided in online supplementary material (Mov-1.)

\section{DAMAGE TO COLONIES}

Badly infested colonies can carry 700 or more adult beetles (personal observations, Donaldson

\section{Life cycle}
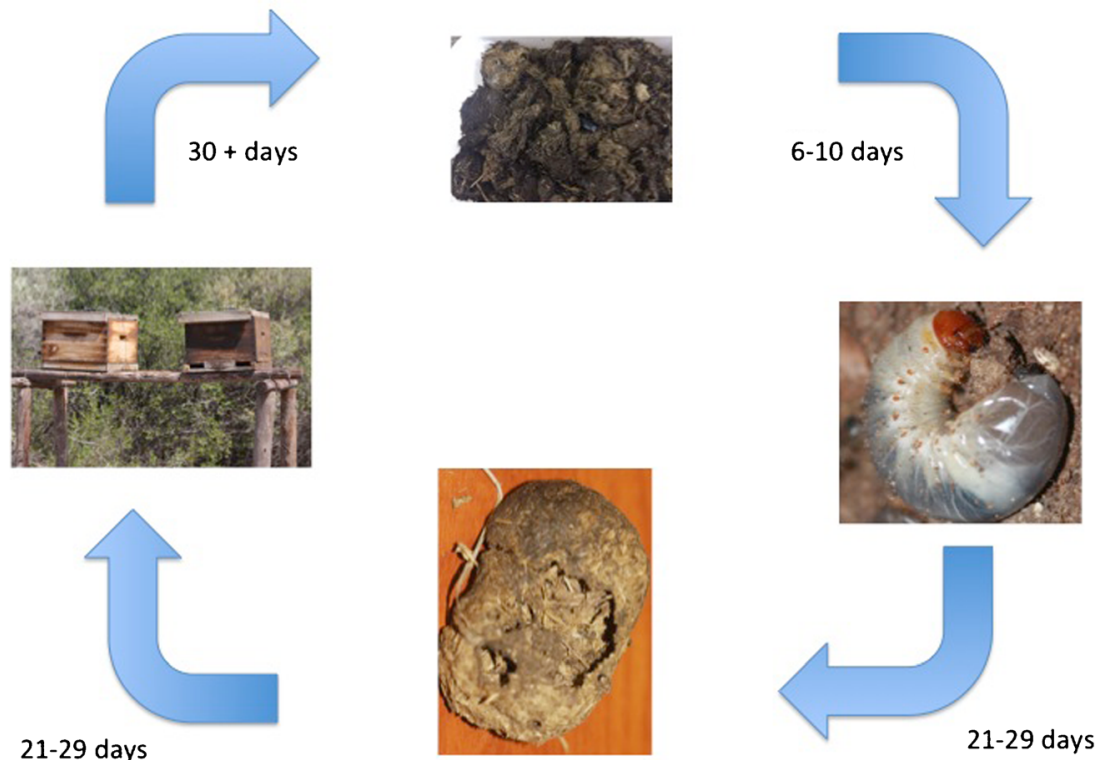

21-29 days

Figure 4. Life cycle of the large African hive beetle Oplostomus fuligineus (reproduced from Oldroyd and Allsopp 2016). 
1989; Fombong et al. 2013). Beetles preferentially feed on young larvae in soft wax, chewing along the midrib of the comb (personal observations). Although beetles will eat pupae, honey, and pollen in the laboratory (Figure 5, Fombong et al. 2013), it is unclear if they do so in the field. Bees rapidly remove damaged larvae and repair honey combs, so that the damage can appear quite minor, even in heavily infested colonies. However, when beetles are confined on brood without bees, the damage caused is clear, obvious, and significant (Figure 5; Fombong et al. 2013).

\section{CONTROL}

In South Africa, Zimbabwe and Botswana, wherever beetles are a problem, hives are provided with a beetle barrier across the entrance (Figure 6, Movie M2). This control method is effective, but requires excellent beekeeping equipment with no holes in the hive material. In infested areas, beekeepers must inspect hives on a fortnightly basis to physically remove and kill beetles.

Adult beetles are attracted by colony volatiles (Fombong et al. 2016) and males by a sex pheromone (Fombong et al. 2012a, b), providing the possibility that beetles could be attracted to pheromone traps.

\section{RISK ASSESSMENT}

The most damaging aspect of SHB biology is their ability to recruit large numbers of adult beetles to a single colony, which is then overwhelmed

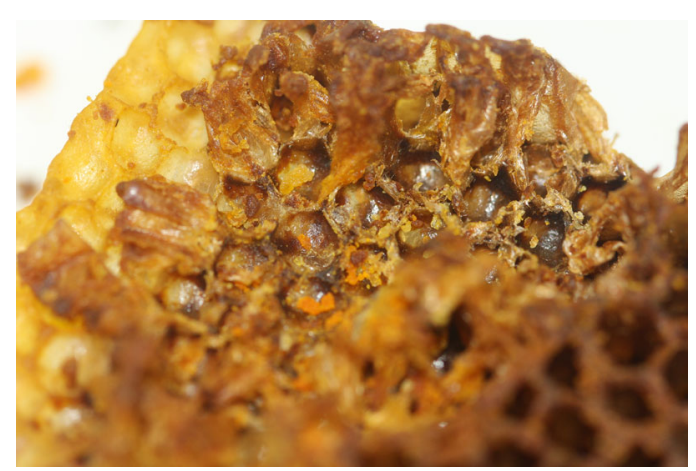

Figure 5. Damage to pollen comb caused by one O. fuligineus overnight (Photo B. Oldroyd).

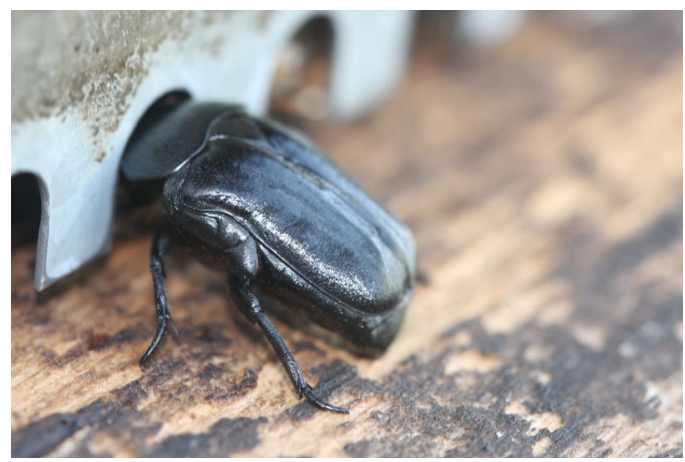

Figure 6. An adult Oplostomus fuligineus is prevented from entering a colony by a beetle guard installed by a beekeeper (Photo B. Oldroyd). See also movie file M2 in online supplementary material.

by beetle larvae that directly consume honey and brood. LAHB larvae grow in dung, and so the larval stage is not a problem in bee colonies. Nonetheless, up to 700 LAHB adult beetles have been reported from a single colony where they can cause a significant damage, and require beekeeper management.

It is important to note that SHB rarely harms bee colonies in Africa, whereas it is devastating elsewhere (Neumann et al. 2016). Thus, the African experience of the damage caused by LAHB may not be indicative of what might happen should LAHB become established elsewhere.

African bees (Apis mellifera scutellata) often propolize the entrance to their colony providing a natural barrier to beetle entry and egress (Figure 7). They can sometimes successfully entomb beetles in propolis, but it is doubtful that

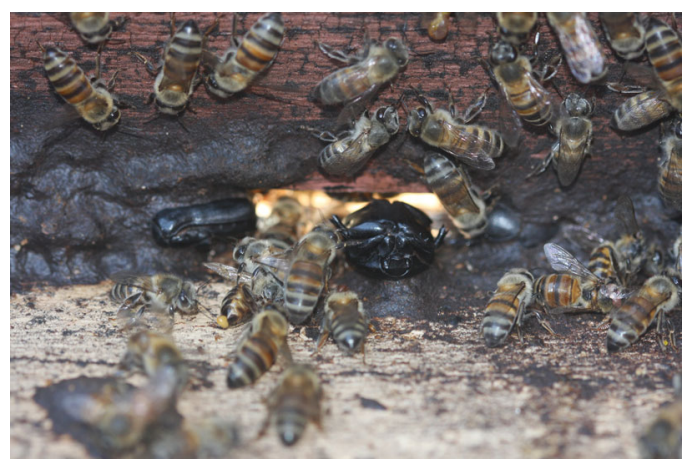

Figure 7. A propolis barrier built by the host colony at the entrance to its hive has prevented this beetle from leaving the hive to lay eggs. 
they can do this with a healthy beetle. While no other effective defenses used by the bees against LAHB have been reported, it is possible that they exist. Honey bees of European origin do not normally propolize the entrance to their colonies (Ruttner 1988), and this would undoubtedly make them more vulnerable to LAHB attack and increase the density of LAHB in the environment. There may be natural enemies of LAHB larvae and pupae in Africa, particularly in dung and soil, which cause mortality. These agents are likely to be absent wherever LAHB becomes invasive.

Because of the extensive pastoral industry based on exotic cattle and the lack of indigenous dung beetles, the dung load in pastures of the Americas and Australasia is much higher than in Africa, providing much greater opportunities for breeding by LAHB. Clearly, the soil types and climate in many areas are sufficiently similar for LAHB to flourish.

Because LAHB are long-lived and probably overwinter in pupal cases in dung, there are numerous plausible routes by which LAHB could be transferred out of Africa into new environments. Transfer of agricultural equipment or soil seems to be the most likely routes. Where horses, cattle, or zoo animals like zebra or bovines are transferred from Africa to international ports, it is very important that all dung be removed prior to release from quarantine. Similarly, returning transport ships used for live cattle export to the Middle East are a significant potential route of entry should the ships make landfall in sub-Saharan Africa.

Adult beetles can survive for $>30$ days without food or water (Oldroyd and Allsopp 2016), so it is conceivable that they could be transferred in a beekeeper's personal effects.

\section{CONCLUSION}

Our survey of LAHB biology shows its significant potential to become a pest of beekeeping worldwide, following the now well-beaten path of Varroa and SHB. We hope that our review will heighten beekeeper and apiculturalist awareness of the devastating potential of Oplostomus to become invasive.

\section{ACKNOWLEDGEMENTS}

We thank Guy Stubbs, Theunis Engelbrecht, Danie Kershof, Henrik Kelly, and Mike Schmolke for the advice, and Guy Stubbs for photographs. We are grateful to Dr. Auka Fombong for supplying the diagnostic characters for Oplostomus and for a very helpful review of this manuscript. This work was funded by a grant from the Australian Rural Research and Development Corporation.

Contributions $\mathrm{BPO}$ and MAH conceived the project and wrote the paper.

\section{ANNEX}

\section{Movie files available in Online supplementary material}

Movie file M1. Adult Oplostomus fuligineus rapidly bury into horse dung.

Movie file M2. An adult Oplostomus fuligineus is prevented from entering a colony by a beetle guard installed by a beekeeper. The beetle is obviously attracted by volatiles from the colony.

Evaluation du risque lié à la présence des grands coléoptères des ruches africains (Oplostomus spp.): synthèse des connaissances

abeilles / espèce invasive / Afrique / ravageur / Apidae / Coleoptera

Risikobeurteilung für den großen afrikanischen Beutenkäfer (Oplostomus spp.): ein Review

Honigbienen / invasive Art / Tierseuche / Apidae / Coleoptera

\section{REFERENCES}

Aebi A., B.E. Vaissière, D. vanEngelsdorp, K.S. Delaplane, D.W. Roubik, P. Neumann (2012) Back to the future: Apis versus non Apis pollination, Trends Ecol. Evol. 27, 142-143.

Aizen M.A., L.A. Garibaldi, S.A. Cunningham, A.M. Klein (2008) Long-term global trends in crop yield and production reveal no current pollination shortage but increasing pollinator dependency, Curr. Biol. 18, 1572-1575. 
Audisio P., F. Marini, E. Gatti, F. Montarsi, F. Mutinelli, A. Campanaro, A.R. Cline (2014) A scientific note on rapid host shift of the invasive dusky sap beetle (Carpophilus lugubris) in Italian beehives: new commensal or potential threat for European apiculture?, Apidologie 45, 464-466.

Bradbear N. (1988) World distribution of major honeybee pests and diseases, Bee Wld. 69, 15-39.

Brittain C., N. Williams, C. Kremen, A.-M. Klein (2013) Synergistic effects of non-Apis bees and honey bees for pollination services, Proceedings of the Royal Society B: Biological Sciences 280, 20122767.

Chantawannakul P., L.I. de Guzman, J. Li, G.R. Williams (2016) Parasites, pathogens, and pests of honeybees in Asia, Apidologie 47, 301-324.

Clauss B. (1983) Bees and Beekeeping in Botswana, Ministry of Agriculture, Gabarone.

Colautti R.I., A. Ricciardi, I.A. Grigorovich, H.J. MacIsaac (2004) Is invasion success explained by the enemy release hypothesis? Ecol Let 7, 721-733.

Corlett R.T. (2001) Pollination in a degraded tropical landscape: a Hong Kong case study, Journal of Tropical Ecology 17, 155-161.

Crane E. (1990) Bees and beekeeping: science practice and world resources, Cornell University Press, Ithaca.

Donaldson J.M.I. (1989) Oplostomus fuligineus (Coleoptera: Scarabadeidae): life cycle and biology under laboratory conditions, and its occurence in bee hives, The Coleopterists Bulletin 43, 177-182.

Eggers O., G. Wurst-Henning (1944) BienenzuchtBienenlebenin Suedwest, Andalusia, South Africa

Ellis J.D., K.S. Delaplane, A. Cline, J.V. McHugh (2008) The association of multiple sap beetle species (Coleoptera: Nitidulidae) with western honey bee (Apis mellifera ) colonies in North America., J. Apic. Res. 47, 188-189.

Elzen P.J., J.R. Baxter, D. Westervelt, C. Randall, K.S. Delaplane, L. Cutts, W.T. Wilson (1999) Field control and biology studies of a new pest species Aethina tumida Murray (Coleoptera, Nitidulidae), attacking European honey bees in the Western Hemisphere, Apidologie 30, 361-366.

Evans J.D., J.S. Pettis, H. Shimanuki (2000) Mitochondrial DNA relationships in an emergent pest of honey bees: Aethina tumida (Coleoptera : Nitidulidae) from the United States and Africa, Ann. Ent. Soc. Am. 93, 415-420.

Folmer O., M. Black, W. Hoeh, R. Lutz, R. Vrijenhoek (1994) DNA primers for amplification of mitochondrial cytochrome c oxidase subunit I from diverse metazoan invertebrates, Molecular Marine Biology and Biotechnology 3, 294-299.

Fombong, A.T., Haas, F., Ddegwa, P.N., Irungu, L.W. (2012a) Life history of Oplostomus haroldi (Coleoptera: Scarabaeidae) under laboratory conditions and a description of its third larval instar, International Journal of Tropical Insect Science

Fombong A.T., F.N. Mumoki, E. Muli, D.K. Masiga, R.T. Arbogast, P.E.A. Teal, B. Torto (2013) Occurence, diversity and pattern of damage of Oplostomus species (Coleoptera: Scarabaeidae), honey bee pests in Kenya, Apidologie 44, 11-20.

Fombong A.T., J.M. Mutunga, P.E.A. Teal, B. Torto (2016) Behavioral evidence for olfactory-based location of honeybee colonies by the scarab Oplostomus haroldi, J Chem Ecol 42, 1063-1069.

Fombong A.T., P.E.A. Teal, R.T. Arbogast, P.N. Ndegwa, L.W. Irungu, B. Torto (2012b) Chemical communication in the honey bee scarab pest Oplostomus haroldi: role of (Z)-9-Pentacosene, J Chem Ecol 38, 1463-1473.

Garibaldi L.A., M.A. Aizen, A.M. Klein, S.A. Cunnigham, L.D. Harder (2011) Global growth and stability of agricultural yield decrease with pollinator dependence, Proc. Nat. Acad. Sci. USA 108, 5909-5914.

Hepburn H.R., S. Radloff (1998) Honeybees of Africa, Springer-Verlag, Berlin.

Hood W.M. (2000) Overview of the small hive beetle, Aethina tumida, in North America, Bee Wld. 81, 129-137.

Hood W.M.M. (2004) The small hive bettle, Aethina tumida: a review, Bee Wld. 85, 51-59.

Johannsmeier M.F. (1980) Beetles that eat brood in South Africa, S. Afric. Bee J. 52, 3-5.

Keeping M.G. (1984) A beetle predacious on the brood of a social wasp, Journal of the Entomological Society of Southern Africa 47, 355-356.

Klein A.M., B.E. Vaissiere, J.H. Cane, I. SteffanDewenter, S.A. Cunningham, C. Kremen, T. Tscharntke (2007) Importance of pollinators in changing landscapes for world crops, Proc. Roy Soc. B. 274, 303-313.

Mutinelli F. (2011) The spread of pathogens through trade in honey bees and their products (including queen bees and semen): overview and recent developments, Rev. Sci. Tech. Off. Int. Epiz. 30, 257-271.

Neumann P., P.J. Elzen (2004) The biology of the small hive beetle (Aethina tumida, Coleoptera : Nitidulidae): gaps in our knowledge of an invasive species, Apidologie 35, 229-247.

Neumann P., J.S. Pettis, M.O. Schäfer (2016) Quo vadis Aethina tumida? Biology and control of small hive beetles, Apidologie 47, 427-466.

Oldroyd B.P., M.H. Allsopp, 2016. Risk assessment for large African hive beetle, Rural Research and Development Corporation, Canberra.

Oldroyd B.P., S. Wongsiri (2006) Asian honey bees. Biology, conservation and human interactions, Harvard University Press, Cambridge, Mas.

Oyerinde A.A., A.T. Ande (2009) Distribution and impact of honeybee pests on colony development in Kwara State, Nigeria, Journal of Agriculture and Social Sciences 5, 85-88.

Papadopoulo P. (1964) Enemies of bees (1), Rhodesia Agricultural Journal 61, 114-115.

Pirk C.W.W., U. Strauss, A.A. Yusuf, F. Démares, H. Human (2016) Honeybee health in Africa - a review, Apidologie 47, 276-300. 
Potts S.G., J.C. Biesmeijer, C. Kremen, P. Neumann, O. Schweiger, W.E. Kunin (2010) Global pollinator declines: trends, impacts and drivers, Trends Ecol Evol 25, 345-353.

Rader R., B.G. Howlett, S.A. Cunningham, D.A. Westcott, L.E. Newstrom-Lloyd, M.K. Walker, D.A.J. Teulon, W. Edwards (2009) Alternative pollinator taxa are equally efficient but not as effective as the honeybee in a mass flowering crop, J. Appl. Ecol. 46, 1080-1087.

Roubik D.W. (1989) Ecology and natural history of tropical bees, Cambridge University Press, Cambridge.

Roubik D.W. (1993) Tropical pollinators in the canopy and understory - field data and theory for stratum preferences, Journal of Insect Behavior 6, 659-673.

Ruter G. (1975) Contribution to the biological study of northern Senegal. Part 28 Coleoptera cetoniidae,
Bulletin de l'Institut Fondamental d'Afrique Noire Serie A Sciences Naturelles 37, 661-668.

Ruttner F. (1988) Biogeography and taxonomy of honeybees, Springer-Verlag, Berlin.

Silberrad R.E.M. (1976) Beekeeping in Zambia, Apimondia, Bucharest.

Swart D.J., M.F. Johannsmeier, G.D. Tribe, P. Kryger (2001) Diseases and pests of honey bees, in: Johannsmeier M.F. (Ed.), Beekeeping in South Africa, Agricultural Research Council, Pretoria, pp. 198-222.

Torto B., A.T. Fombong, D.M. Mutyambai, E. Muli, R.T. Arbogast, P.E.A. Teal (2010) Athena tumida (Coleoptera: Nitidulidae) and Oplostomus haroldi (Coleoptera: Scarabaiidae): occurence in Kenya, distribution within honey bee colonies, and responses to host odours, Ann. Ent. Soc. Am. 103, 389-396. 